DOI: $10.2478 / v 10025-007-0006-6$

JOURNAL OF WATER

AND LAND DEVELOPMENT

J. Water Land Dev. No. 10, 2006: 67-78

\title{
The protection of wetlands as valuable natural areas and water cycling regulators
}

\author{
Waldemar MIODUSZEWSKI
}

Institute for Land Reclamation and Grassland Farming, Department of Water Resources, Falenty, 05-090 Raszyn, Poland; w.mioduszewski@imuz.edu.pl

\begin{abstract}
Wetlands play a significant role in agricultural landscape. They are the areas of exceptionally great natural values able to regulate water cycling in river catchments. In many cases they are the basic food source for bred animals.

Large areas of wetlands (c. 4 million ha) have been drained for agricultural purposes in Poland. Nevertheless, there are still numerous natural (or close to natural) wetlands, part of which is protected in nature reserves or national parks.

Having in mind the transformation of agriculture and the need of protecting water resources and natural environment, it is necessary to regulate the principles of utilisation and management of reclaimed wetlands. Water management should be adjusted to the type of an area and to environmental requirements. Regardless of the type and intensity of agricultural use of wetlands one has to aim at limiting rapid outflow of spring thaw and rainfall waters which means the reconstruction and increasing of natural retention capacity of the river catchment. It is necessary to provide an appropriate number of water lifting facilities and their proper exploitation in land reclamation objects.

It is as well necessary to create appropriate organizational, legal and financial conditions stimulating actions to improve water balance and wetland protection.
\end{abstract}

Key words: irrigation-drainage system, river basins, water balance, wetlands

\section{INTRODUCTION}

Wetlands play a significant role in agricultural landscape. They are the areas of exceptionally great natural values able to regulate water cycling in river catchments. In many cases they are the basic food source for bred animals. Man since the dawn of time interfered in water cycling by actions aimed at intensifying agriculture in wet areas. Man built flood embankments, water reservoirs and reclamation systems. These activities largely enhanced civilization and economic development through e.g. limiting the effects of disasters like floods and droughts or making wetlands available for agricultural production. Economic activity resulted also in unfavourable alteration of the natural environment. Rapid discharge of 
spring waters or heavy rains worsened the structure of water balance (increased seasonal variability of flows in running waters) and decreased the already slender water resources in Poland.

Particularly harmful and unfavourable natural transformations take place in wetlands drained for agricultural purposes. Vegetation cover becomes totally reshaped. Crop plants are being introduced in place of naturally diversified flora and fauna. Excessive irrigation and improper exploitation of draining and irrigation systems lead to the degradation of organic matter in soil, to the decrease of biodiversity and water retention capacity of wetlands.

The importance of wetlands and their effect on water cycling in catchments are more and more acknowledged by public opinion worldwide. Protection of wetlands has been the subject of many international conventions, best known of which is the Ramsar Convention of 1971. Wetland protection is also dealt with in the Water Framework Directive of the European Union. It obliges the member countries to protect "terrestrial ecosystems and wetlands directly dependent on aquatic ecosystems" as natural regulators of water cycling in nature. Large part of wetlands is protected as an effect of "Bird" and "Habitat" directives and included into the areas of Natura 2000.

Large areas of wetlands (c. 4 million ha) have been drained for agricultural purposes in Poland. Nevertheless, there are still numerous natural (or close to natural) wetlands, part of which is protected in nature reserves or national parks. Some excessively wet grounds are abandoned by farmers. Most non-forested wetlands, however, are and still will be used by agriculture mainly as meadows and pastures of extensive production. It is thus necessary to reconcile the interest of agriculture and natural environment and such wetland utilisation as to enable them functioning as water regulators in catchments.

\section{WATER-RELATED ECOSYSTEMS - PRESENT STATUS AND THREATS}

Water Framework Directive of the European Union (Directive 2000/60/EU) recommends to protect terrestrial ecosystems and wetlands, which are directly dependent on aquatic ecosystems and can be termed in short "water-related ecosystems". According to the Article 6 of the Directive, the term involves areas that require particular protection to preserve habitats and species directly dependent on water. Appendix IV of the Directive defines these areas as such, where the maintenance or improvement of water status is an important prerequisite for their protection.

The term "water-related ecosystems" in its broad sense might be synonymous to "wetlands", "hydrogenic sites" or "wet areas". Wetlands are understood as areas with hydrophilous vegetation and surface deposits accumulated by water (peat, mud, alluvia). Wetlands where organic matter accumulates in a form of peat are 
called peatlands, other - non-peat wetlands (DEMBEK, 2002; OKRUSZKO, 1992). Sometimes the term "wetland" is used for sites secondarily transformed due to drainage, particularly when they have a potential natural value and can be restored. River valleys and all terrain depressions with high ground water level decisive for vegetation status can also be assumed "water-related ecosystems".

Part of wetlands that conforms to the requirements of the Habitat (Directive 92/43/EEC) and Bird (Directive 79/409/EEC) directives is protected within the Natura 2000 programme. It is, however, only part of wetlands important for water management. The remaining wetlands are used by agriculture and often equipped with draining (seldom with irrigating) facilities. Rational water management adjusted to practical needs and to the type of habitat should be carried out in all wetlands both within the Natura 2000 and in those not protected.

Broadly understood wetlands occupy an area of 4345400 ha i.e. nearly $14 \%$ of the country area. It is estimated that $15 \%$ of the total area of natural and transformed wetlands is covered by forest habitats and shrub communities. The remaining areas are mainly occupied by grasslands, fallow lands and sometimes even by croplands (ILNICKI, 2002).

Over $80 \%$ of wetlands, including hydrogenic forest sites, have been drained to intensify agricultural and forest production. No complete data are available to estimate the transformation of all wetlands, the type of land use and protection of their natural values. More detailed inventories were made for peatlands only (Table 1). Presented data indicate that only $9 \%$ of peatlands remained in the natural or close to the natural status. It might be assumed that the percent of natural (not drained) non-peat wetlands is even smaller.

Table 1. The use of peatlands (www.gridw.pl/raport)

\begin{tabular}{l|c|c}
\hline \multicolumn{1}{c|}{ The type of use } & $\begin{array}{c}\text { Area } \\
\text { thousand ha }\end{array}$ & $\begin{array}{c}\text { Share } \\
\%\end{array}$ \\
\hline Natural peatlands & 12.0 & 8.8 \\
Meadows & 960.0 & 70.7 \\
Forests & 120.0 & 8.8 \\
Post-peat & 150.0 & 11.0 \\
Protected peatlands & 6.1 & 0.4 \\
Exploited peatlands (peat dredging) & 2.5 & 0.2 \\
Total & 1358.6 & 100 \\
\hline
\end{tabular}

Permanent grasslands, except for the mountain ones, closely associated with grounds of high ground water table, occupy an area of c. 5 million ha. In that number 2 million ha (including practically all peatlands) were equipped with draining systems. In only $25 \%$ of drained areas (c. 500000 ha) there is a potential possibil- 
ity of irrigation with the so-called capillary raising method through maintaining a high water level in the draining ditches. Now, only less than 100000 ha $(5 \%$ of drained area) are irrigated. A lack of irrigation in hydrogenic sites and their drying pose a threat for both the natural environment and for the structure of water balance in catchments. Draining ditches rapidly discharge waters in spring thus enhancing the flood risk and leading to water deficits in summer (MALTBY et al., 1994; MIODUSZEWSKI, 1999; VERRY, 1988; WILGAT, 1976).

Noteworthy, due to intensification of agriculture and to land development many wetlands were totally liquidated. Present area of peatlands is thought to cover at least $20 \%$ less area from that in the XIX century.

Most wetlands, including those not drained, are used in agriculture - in Poland mainly as grasslands. Meadows and pastures in wet areas are valuable ecosystems whose natural values largely depend on maintaining the extensive agricultural production (DEMBEK, 2002).

Wetlands are interesting objects for water management as water cycling regulators (OKRUSZKO, 2005), for ecology as the areas of high biological values and for agriculture as the sources of animal fodder.

Intensive agriculture but also abandoning of agricultural use are the threats for biological values of wetlands. Wetlands, particularly those partly drained, abandoned by agriculture quickly overgrow with trees and shrubs. Natural values (biodiversity) decline. The disappearance of large open meadow areas is especially unfavourable for many bird species (DEMBEK, 2002).

The accession of Poland to the European Union poses some threats to wetlands but brings also the chance of extending their protection. The threats arise from the policy of enlarging farms and from intensification of agriculture. Liquidation of wetlands is being observed in large private farms. The chance for wetlands is in the possibility of their legal protection. This is particularly valid for wetlands in areas difficult for agricultural use where production has been abandoned. Wetland protection in agricultural landscape is reflected in the Programme for the development of rural areas for the years 2007-2013 and in implemented agroenvironmental programmes (Program..., 2006). Financial compensation is anticipated for farmers who possess valuable wetlands in their farms. The Water Framework Directive should play an important role in wetland (water-related systems) protection. Wetlands are the areas of high natural values but also play a role of water cycling regulators in catchments and restrict the dispersion of pollutants.

\section{THE EFFECT OF WETLANDS ON WATER RELATIONS IN A RIVER CATCHMENT}

Geology and climate are the factors responsible for the input and output of water from wetlands. Wetlands do not produce water themselves. They might, 
however, affect water cycling in a river catchment (GUTRY-KORYCKA et al., 2005; OKRUSZKO, 2005). The influence of wetlands on hydrologic regime differs between dry periods and the periods of high water stages. Water flows out of wetlands (including fluviogenic peatlands fed with flood waters) in the vegetation period due mainly to evapotranspiration. It is estimated that in our climatic zone over $70 \%$ of water leaves natural wetlands in that way (MIODUSZEWSKI et al., 1996; WORONKO, 2005). No more than $30 \%$ of water feeds streams flowing through wetland area. It might approximately be assumed that during dry periods (e.g. in the vegetation season) a river is fed with water retained in soil at a rate not exceeding $0.05-0.1 \mathrm{dm}^{3} \cdot \mathrm{s}^{-1} \cdot \mathrm{km}^{-2}$ (MIODUSZEWSKI, 1999). That is much smaller amount than that delivered to a stream by ground waters flowing from mineral aquifers. Therefore, feeding a river with water retained in peat does not exert a substantial effect on hydrologic regime and water resources in the river catchment at low flows.

Slightly different is the effect of wetlands on hydrologic regime in the zone of waters under pressure including the area of soligenic peatlands. Poorly permeable layer of organic deposits covering the bottom and slopes of a river valley hampers the outflow of ground water from adjacent areas and increases piesometric pressure in mineral aquifers. In such wetlands the springs and effluent seepages rich in water are very frequent. Water retained in the pores of organic matter (peat, soil) does not, however, feed a river; it is rather fed with ground water from extent mineral aquifers in upland. Instead, wetlands hamper the outflow of water and lift the water table in mineral aquifers contributing thus to the increase of ground water resources and to the reduction of discharge variability.

Wetlands, particularly those in river valleys, may largely affect flood flows. When large part of the catchment is covered by peatlands, the reduction of peak flow is clearly visible. Thirty percent of catchment basin occupied by peatlands may reduce maximum flow by $60-80 \%$. Small peat complexes situated outside the valley exert lesser effect on high water flows. They affect hydrologic regime as the so-called isolated areas (without flow) through restricting rapid surface runoffs.

Regardless of their size and contribution to the total catchment area, wetlands, particularly those in compact complexes, exert some effect on water cycling in a catchment. They decrease the flood waves and prolong water discharge from a valley in various degrees. The larger the wetland and the wider the valley, the more distinct is their effect on hydrologic regime of a river.

The impact of wetlands on flows in running waters depends less on retention capacity of the soil in the zone of ground water level fluctuations. Maximum flows are more affected by the width of and land use in the river valley. Flood waters fill soil pores and then spills over the land surface. After the decline of river water levels the water flows out of the valley. The flow is, however, low due to a high hydraulic roughness coefficient resulting from land relief, from bog vegetation overgrowing wetlands (in spring it is an unmown, dry vegetation) and from small longi- 
tudinal and crosswise slopes of wet valleys. To sum up, the great impact of natural wetlands on the intensity of maximum flows in a river arises mainly from the character and shape of the river valley and from the roughness coefficient of flooded area and to a less extent from retention capacity of the soil profile (pore volume of organic soil). It is estimated, that $10 \mathrm{~km}$ wide valley of the Biebrza River retains almost 10 million $\mathrm{m} 3$ of water during spring floods limiting thus flood waves in the lower course of the river (OKRUSZKO, 2005).

\section{THE EFFECT OF WETLAND DRAINING ON HYDROLOGIC REGIME OF WATER COURSES}

The construction of a draining system in wetlands exerts variable effect on hydrologic regime of the catchment basin. The extent of such impact depends on hydrologic conditions, depth and spanning of ditches, soil thickness and permeability, the type of hydrologic recharge etc. (OKRUSZKO, 1992).

After the construction of draining ditches the ground water table declines and so does the moisture of the upper soil layers. At a sparse draining network the dynamics of ground water table fluctuation is often similar to that in not drained areas but remains at lower ordinates. After draining, high water stages usually occur less frequently and are of shorter duration. At a dense draining network the amplitude of ground water fluctuations is smaller, low stages markedly deepen and sometimes water table declines beneath the bottom of ditches due to evapotranspiration.

Shortly after the construction of draining ditches a large volume of water, formerly retained in soil pores and in aquifers adjacent to the wetland, is released. Ground water table within the wetland and in nearby uplands declines. Water flowing out of wetland and from adjacent grounds increases the intensity of river discharge. More water flows out of the wetland than it would appear from the difference between evapotranspiration and atmospheric precipitation. Therefore, the increase of water discharge is being observed during two-three years after the construction of ditches (ALEKSIEJEVSKIJ, 1980; IVICKI and SVEDOVSKI, 1981).

The decline of ground water table in wetlands alters evapotranspiration. After the construction of a draining system the evapotranspiration usually decreases because of limited evaporation from free water table and because water is less available to plants at deeper ground water layers. In many cases new plant species have smaller water demands. Smaller evapotranspiration makes larger water volumes discharged to rivers through the draining system. Water discharge in the river is thus larger than that before reclamation. Increased mean river flows after the construction of the draining systems was observed e.g. in the Narew River (BYCZKOWSKI and MANDES, 1996).

The reverse phenomenon is also observed when intensive crops or the introduction of water consuming plants (e.g. reed) into the drained valley result in sub- 
stantial increase of evapotranspiration which may further decrease the ground water table. This may lead to decreasing annual water discharge from wetland and thus decreasing of the water flow in a stream. Preliminary studies in the Narew valley demonstrate that the invasion of reed instead of sedges and inefficient meadows in the river valley lowered the ground water table and increased mineralisation of organic matter (Gospodarowanie..., 2002).

Lowering of the ground water table in drained wetlands fills greater volume of soil pores with air thus increasing the instantaneous retention capacity of soil profile. When ground water in natural wetlands remains near surface the year round, soil retention is negligible. Hence, a small volume of water permeates down the soil profile after rainfall. Most precipitation is left on the surface and slowly flows down to the river. The flow, as shown above, is very slow due to a high hydraulic roughness of the wetland surface. In drained wetland, a greater volume of precipitation is retained in soil profile resulting sometimes in substantial elevation of ground water table. Retention capacity of the soil is, however, limited and after complete fulfilment of pores water flows to the river on the surface. This flow is much faster in wetlands equipped with draining ditches as compared with that in not drained areas. A great velocity of water flow from the valley to river is a result of small hydraulic roughness of intensively managed, levelled surface of wet meadow or pasture and of the presence of a dense network of draining ditches. Even single ditches constructed in the river valley are able to accelerate water runoff from the valley (MIODUSZEWSKI, 1999). Noteworthy, in spite of the greater soil retention of drained wetlands, their actual retention capacity is much smaller than that of wetlands of natural character.

Unfavourable impact of draining systems on water cycling in a catchment may be markedly limited. This may be achieved e.g. through appropriate water management in reclamation objects. Basic task in the exploitation of such objects should be to increase retention in soil and ditches and to hamper the rapid outflow of water out of the wetland (Stanowisko..., 1996). To achieve this, one has to build weirs and falls on ditches and to keep high water stages.

Appropriate exploitation of reclamation systems requires the understanding of their effects on natural environment and water resources. Regulation of water relations depends on the type of wetland, hydrologic recharge, hydrogeologic conditions etc. Economical management of water resources is necessary and may be performed through retaining spring and rainfall waters in reclamation ditches, soil profiles and in aquifers adjacent to wetland. Reclamation systems in river valleys equipped with properly exploited damming facilities are able to store large amounts of water from the catchment and may thus improve the structure of water balance (limit floods and the consequences of droughts). 


\section{LEGAL PROTECTION OF WETLANDS}

The highest protective status deserved by most valuable natural areas is given in Poland to 23 national parks of a total area of 314527 ha (Table 2).

Table 2. Types of habitats in national parks

\begin{tabular}{l|c|c}
\hline \multirow{2}{*}{\multicolumn{1}{c}{ Type of habitat }} & \multicolumn{2}{c}{ Area } \\
\cline { 2 - 3 } & thousand ha & $\%$ \\
\hline Forests & 190730 & 60.7 \\
Agricultural lands & 43823 & 13.9 \\
Waters & 22749 & 7.2 \\
Lands of ecological use (wetlands) & 37927 & 12.1 \\
Other & 19298 & 6.1 \\
Total & 314527 & 100 \\
\hline
\end{tabular}

Forest habitats are the most often protected sites (60.7\%) but in practically every national park there are waters $(7.2 \%$ and water related habitats $(12.1 \%)$. Four national parks, however, were created mainly for the purpose of protecting wetlands. These parks include:

- the Polesie National Park - established in 1990 as the first park in Poland, whose main aim was to protect valuable wet forests, meadows and open peatlands. The park covers an area of 9762 ha including 4204 ha of forests, 1445 ha of grasslands (mostly not used) and 2343 ha of the most valuable ecosystems - nonforested peatlands. There are numerous water bodies overgrown to a different degree of a total area of 477 ha.

- the Biebrza National Park - established in 1993 is the largest park in Poland. Its area is 59223 ha with 15547 ha covered by forests, 18182 ha of agricultural lands and 25494 ha of the most valuable natural ecosystems - the famous Biebrza marshes. The park situated in the Biebrza River valley has a great hydrologic importance. Up to $15 \mathrm{~km}$ wide and flat valley is covered by organic soils of large retention capacity estimated at several million $\mathrm{m} 3$ and can thus markedly reduce flood waves.

- the Narew National Park - established in 1996 involves swampy valley of the Narew River between Suraż and Rzędziany of an area of 7350 ha. Hydrogenic sites - mainly open meadows and anastomosing river that occupy over $90 \%$ of the park's area are protected there.

- the National Park "Ujście Warty" - established in 2001 covers an area of 8038 ha. Over $90 \%$ of the park's area comprises extensive meadows and pastures on organic grounds. The park situated in the Warta deltaic outlet to the Odra is flooded every spring. 
Large wetlands can also be found in the Kampinos National Park (1 $377 \mathrm{ha}$ ) and in the Słowiński National Park (2 427 ha).

Basic problem in the protection of natural values in "marshy" natural parks is to maintain high moisture of hydrogenic sites and to preserve large open meadows. The second condition is determined by the need of maintaining appropriate conditions for many waterfowl species. Therefore, hydrotechnical works aimed at limiting water outflow, liquidation of the existing artificial canals and ditches are anticipated in the plans of nature protection in national parks. On the other hand, however, extensive grassland management is preserved or restored in wetlands to prevent the succession of undesired shrubs or reeds there. Financial compensation is anticipated in agro-environmental programmes for farmers who undertake every year mowing of formerly abandoned meadows (Program..., 2006).

Wetlands are encompassed by various other forms of legal protection. Two large landscape parks of an area of several dozen $\mathrm{km}^{2}$ (the Landscape Park of the Narew Valley near Łomża and the Landscape Park of the Lower Odra) are situated in river valleys. The first involves part of the natural valley of the middle Narew with dominating hydrogenic sites. The second is located between flood embankments on grounds formerly drained and intensively used by agriculture. Now, it is a valuable ecosystem.

There are several thousand of small (some hundred hectares each) protected areas in Poland. These are nature reserves and the so-called lands of ecological use. At least half of these objects were created to protect aquatic ecosystems or hydrogenic sites. They provide a valuable diversification of agricultural landscape and play a positive role for water cycling within small river catchments.

In spite of numerous destructions, there are many wetlands in the country which are not legally protected. They are situated partly in areas abandoned by agriculture but some can be found in regions of intensively developing agriculture. There is justified fear that some of them might be liquidated. Some hopes concerning maintenance and protection of wetlands could be associated with the implementation of the Natura 2000 programme. It is proposed to involve $11 \%$ of the country area, including almost all river valleys and other wetlands, into this programme.

\section{CONCLUSIONS}

1. Hydrogenic sites (wetlands) closely associated with water conditions (high ground water tables) are biologically valuable areas largely responsible for biodiversity of agricultural landscape. They affect water cycling and are used in agriculture as meadows and pastures. In many regions they are the basic fodder sources for cattle. 
2. To enable agricultural utilisation of wetlands in Poland, c. 2 million ha of hydrogenic sites situated in river valleys and terrain depressions were drained. Only 0.5 million ha of this number were equipped with facilities providing capillary irrigation or controlled water outflow. Now, irrigation is carried out in less than 100 thousand ha. Poor technical status, improper exploitation and a lack of damming facilities have resulted in excessive drainage and decreased retention capacity of wetlands and, consequently, in:

- rapid, uncontrolled outflow of snow melting waters and rainfalls which have led to the increased frequency of extreme phenomena (floods and droughts) and to the decrease of water resources in catchments,

- decreased level of ground waters leading to overdrying and degradation of organic soils, to mineralization of organic matter and the disappearance of peatlands,

degradation of the natural values of river valleys, decreased diversity of flora and fauna,

- decreased agricultural value of grasslands, decreased yields due to water deficits in vegetation period,

- pollution of surface waters with nitrogen compounds released during the mineralization of organic matter.

3. Having in mind the transformation of agriculture and the need of protecting water resources and natural environment, it is necessary to regulate the principles of utilisation and management of reclaimed wetlands. Water management should be adjusted to the type of an area and to environmental requirements. Regardless of the type and intensity of agricultural use of wetlands one has to aim at limiting rapid outflow of spring thaw and rainfall waters which means the reconstruction and increasing of natural retention capacity of the river catchment. It is necessary to provide an appropriate number of water lifting facilities and their proper exploitation in land reclamation objects.

4. It is necessary to create appropriate organizational, legal and financial conditions stimulating actions to improve water balance and wetland protection, in particular to include small agricultural catchments into consistent management system for catchments and river basins and to implement the system of financial compensation for the retention of snow melt and rainfalls. It is necessary to consider the protection of water resources and wetlands in the Programme of Rural Development for the years 2007-2013 and in agro-environmental programmes.

\section{REFERENCES}

1. AleKsiejeVSKIJ V.J., 1980. Vlijanie osušenija na gruntovye vody. (The effect of drainage on ground waters). Gidrotech. Melior. nr 7. 
2. BYCZKOWSKI A., MANDES B., 1996. Badania zmian natężenia średnich przepływów w rzekach Polski Północno-Wschodniej. (The study on the changes of mean flows in rivers of north-eastern Poland). Wiad. IMGW t. 19(40) z. 1.

3. Council Directive 79/409/EEC of 2 April 1979 on the conservation of wild birds: http://www.ecnc.nl/doc/europe/legislat/birdsdir.html

4. Council Directive 92/43/EEC of 21 May 1992 on the conservation of natural habitats and of wild fauna and flora: http://www.ecnc.nl/doc/europe/legislat/habdire.html"

5. Directive 2000/60/EC of the European Parliament and of the Council of 23 October 2000 establishing a framework for Community action in the field of water policy: http://www.ecnc.nl/doc/europe/legislat/conveu.html\#direc

6. DEMBEK W., 2000. Wybrane aspekty zróżnicowania torfowisk w młodo- i staroglacjalnych krajobrazach Polski Wschodniej. (Selected aspects of diversification of peatlands in the young and old glacial landscapes of eastern Poland). Rozpr. Habil. Falenty, IMUZ.

7. Gospodarowanie wodą w łęgowej dolinie górnej Narwi, 2002. (Water management in riparian valley of the upper Narew). Red. W. Mioduszewski. Falenty, Wydaw. IMUZ.

8. GUTRY-KorycKa M., NAwrockA B., SOCZYŃSKA U., 2005. Rola retencji w kształtowaniu wezbrań opadowych. (The role of water retention in the formation of rainfall floods). Warszawa, Wydaw. UW.

9. ILNICKI P., 2002. Torfowiska i torf. (Peatlands and peat). Poznań, Wydaw. AR.

10. IVICKI A.I., SvedovsKi P.V., 1981. Osuašenije bolot i vodnyj režim prilegajuaščich teritorii. (Wetland drainage and the hydrologic regime of adjacent areas). Gidrotech. Melior. 9.

11. KowALEWSKI Z., 2003. Wpływ retencjonowania wód powierzchniowych na bilans wodny małych zlewni rolniczych. (The effect of surface water retention on water balance in small agricultural catchments) Woda Środ. Obsz. Wiej. Rozpr. nauk. monogr. 6.

12. Maltby E., Hogan D.V., Immirzi C.P., Tellam J.H., VAn Der PeiJi M.J., 1994. Building a new approach to the investigation and assessment of wetlands ecosystem functioning. In: Global wetlands: Old world and new. Ed. W.J. Mitch. Amsterdam, Elsevier.

13. MiodUSzEwSKI W., 1996. Rola torfowisk w kształtowaniu zasobów wodnych i ich związek z małą retencją. (The role of peatlands in the formation of water resources and their relation to small retention). Melior. Rol. 3/4.

14. MioduszewSKi W., 1999. Kształtowanie i ochrona zasobów wodnych w krajobrazie rolniczym. (Management and protection of water resources in agricultural landscape). Falenty, IMUZ.

15. Mioduszewski W., Szuniewicz J., Kowalewski Z., ChrZANowski S., Ślesicka A., Borowski J., 1996. Gospodarka wodna jako podstawa podziału torfowisk. (Water management as a basis for the division of peatlands). Wiad. IMUZ 4 (2).

16. OKRUSzKo H., 1992. Siedliska hydrogeniczne, ich specyfika i zróżnicowanie. (Hydrogenic sites, their specifics and diversity). Bibl. Wiad. IMUZ 79.

17. OKRUSZKO T., 2005. Kryteria hydrologiczne w ochronie mokradel. (Hydrologic criteria in the protection of wetlands). Pr. nauk. monogr. Warszawa, SGGW.

18. Program rozwoju obszarów wiejskich na lata 2007-2013, 2006. (Programme for the development of rural areas in the years 2007-2013). Projekt W-06/VII/06. Warszawa, MRiRW.

19. Stanowisko Komitetu Melioracji I Inżynierii Środowiska Rolniczego PAN w sprawie odbudowy retencji wodnej siedlisk hydrogenicznych, 1996. (Stand of the Committee of Land Reclamation and Engineering of Agricultural Environment Pan on the reconstruction of water retention in hydrogenic sites). Warszawa maszyn.

20. VERRY E.S., 1988. Wetlands and water. Water Quality Bull. Man. Wetland vol. 13.

21. Wilgat T., 1976. Zmiany stosunków wodnych Niziny Sandomierskiej pod wpływem prac hydrotechnicznych. W: Wpływ melioracji wodnych na środowisko przyrodnicze. (Alteration of water relations of Sandomierska Lowland under the effect of hydrogenic works. In: Influence of water reclamation on the natural environment). Mater Konf. Jadwisin. Warszawa, PAN. 
22. WORONKO D., 2005. Rola torfowisk górskich w obiegu wody(na przykładzie Wielkiego Torfowiska Batorowskiego). (The role of mountain petlands in water cycling - an example Wielkie Torfowisko Batorowskie. PhD thesis). Warszawa, UW, pr. dokt.

\section{STRESZCZENIE}

Ochrona mokradel jako cennych obszarów przyrodniczych i terenów użytkowanych rolniczo oraz regulatorów obiegu wody

Słowa kluczowe: bilans wodny, mokradta, systemy melioracyjne, zlewnie rzeczne

Siedliska hydrogeniczne (mokradła), ściśle związane z warunkami wodnymi (wysoki poziom wód gruntowych), są cennymi przyrodniczo obszarami, decydującymi w dużym stopniu o biologicznej różnorodności krajobrazu rolniczego. Wywierają wpływ na obieg wody w przyrodzie, a jednocześnie są obszarami wykorzystywanymi przez rolnictwo jako łąki i pastwiska - w wielu regionach kraju stanowią podstawowe źródło pozyskania paszy dla bydła.

Biorąc pod uwage zachodzące zmiany $\mathrm{w}$ gospodarce rolnej oraz potrzeby ochrony zasobów wodnych i środowiska przyrodniczego, niezbędne jest uregulowanie zasad wykorzystania i użytkowania zmeliorowanych obszarów mokradłowych. Gospodarka wodna powinna być dostosowana do typu obszaru i wymagań środowiska przyrodniczego. Bez względu na sposób i intensywność rolniczego użytkowania mokradeł należy dążyć do zahamowania szybkiego odpływu wód roztopowych i opadowych, co jest równoznaczne z odbudową, a nawet zwiększeniem naturalnej retencyjności zlewni rzecznej. Na obiektach melioracyjnych niezbędne jest zapewnienie odpowiedniej liczby budowli i urządzeń piętrzących wodę oraz prowadzenie prawidłowej eksploatacji (gospodarki wodnej). Ochrona mokradeł będzie skuteczna, jeśli zostaną utworzone odpowiednie uwarunkowania organizacyjne, prawne i finansowe, stymulujące podejmowanie działań dla poprawy bilansu wodnego i zwiększania uwilgotnienia obszarów mokradłowych.

Reviewers:

Received 8.11.2006 r.

Prof. assist. Wiesław Dembek

Prof. Tomasz Okruszko 